\title{
Effect of Solution Annealing on Austenite Morphology and Pitting Corrosion of Super Duplex Stainless Steel UNS S 32750
}

\author{
Changwon Sung ${ }^{1}$, Byung-Hyun Shin ${ }^{2, *}$, Wonsub Chung ${ }^{2, *}$ \\ ${ }^{1}$ Kowel corporation, Yangsan, Korea \\ ${ }^{2}$ School of Materials Science and Engineering, Pusan National University, Busan 46241, Republic of \\ Korea \\ *E-mail: $\underline{\text { lemonhouse@ pusan.ac.kr, wschung1@ pusan.ac.kr }}$
}

doi: $10.20964 / 2021.08 .08$

Received: 2 April 2021 / Accepted: 12 May 2021 / Published: 30 June 2021

\begin{abstract}
The pitting corrosion resistance of super duplex stainless steel (SDSS) varies depending on heattreatment conditions. Therefore, in this study, the volume fraction and morphology of austenite on SDSS were controlled in 6 samples, and the effect on the pitting corrosion after solution annealing was analyzed to of the critical pitting temperature (CPT). The pitting-resistance equivalent $(\mathrm{PRE}=\mathrm{wt} \% \mathrm{Cr}+3.3 \mathrm{wt}$ $\% \mathrm{Mo}+16 \mathrm{wt} \% \mathrm{~N}$ ) was became equal by solution annealing, but the CPT exhibited varying values. Despite heat treatment of the solution annealing, the CPT increased by $15.9{ }^{\circ} \mathrm{C}$ from $67.5^{\circ} \mathrm{C}$ to $83.4{ }^{\circ} \mathrm{C}$. The solution annealing removed the segregation of the chemical composition and assisted in improving the PRE; however, it not removed in a non-uniform morphology of austenite. Therefore, the corrosion resistance of SDSS can be optimized by appropriately controlling the morphology of austenite during the manufacturing process.
\end{abstract}

Keywords: Solution annealing, Austenite morphology, Volume fraction, Pitting corrosion, Super duplex stainless steel.

\section{FULL TEXT}

(C) 2021 The Authors. Published by ESG (www.electrochemsci.org). This article is an open access article distributed under the terms and conditions of the Creative Commons Attribution license (http://creativecommons.org/licenses/by/4.0/). 